\title{
酸性官能基を導入した多孔質炭素のアンモニア吸着特性
}

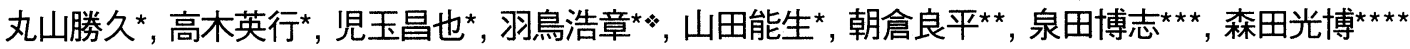 \\ (平成15年4月3日受理, 平成15年6月9日採択)
}

\section{Ammonia Adsorption on Porous Carbons with Acidic Functional Groups}

\author{
Katsuhisa Maruyama*, Hideyuki Takagi*, Masaya Kodama*, Hiroaki Hatori**, Yoshio Yamada*, \\ Ryohei Asakura $^{* *}$, Hiroshi Izumida*** and Mitsuhiro Morita****
}

\begin{abstract}
Activated carbon and bamboo charcoal were modified by the liquid phase oxidation using $\left(\mathrm{NH}_{4}\right)_{2} \mathrm{~S}_{2} \mathrm{O}_{8}$ and the ammonia adsorption properties were investigated. The amount of acidic functional groups on activated carbon increased with treatment time in $\left(\mathrm{NH}_{4}\right)_{2} \mathrm{~S}_{2} \mathrm{O}_{8}$ solution. The introduction of acidic functional groups caused an increase of the amount of chemisorbed ammonia as well as the improvement of physisorption properties at low relative pressures. The bamboo charcoal showed higher potential of ammonia physisorption than the activated carbon, though the ammonia adsorption ability was unchanged by liquid phase oxidation because acidic functional groups were hardly introduced on the surface.
\end{abstract}

KEYWORDS : Activated carbon, Bamboo charcoal, Acidic functional group, Ammonia adsorption

\section{1. 緒 言}

活性炭は, 吸着材として消臭や水質浄化, 工業的な精製・分 離・回収プロセスなどさまざまな分野で利用されている。表 面が基本的に無極性であることが炭素系吸着材の1つの特徴 であるが, 反面, アンモニアや硫化水素など極性分子の吸着に おいては相互作用力が小さいことが欠点となる場合もあり， 実用的には酸塩基性化合物の添着などの表面修飾によって吸 着性能の改善が図られている11,2)。アンモニアはさまざまな 悪臭の原因物質の 1 つであることから, 消臭用吸着材の性能評 価の対象物質の1つとなっている。また, 触媒分野において, アンモニアの昇温脱離 (TPD) スペクトルの解析は吸着材表 面の酸性部位の解析法として広く用いられているほか, 金属 担持活性炭のミクロ孔内でのアンモニア合成なども検討され ている31.4)。活性炭へのアンモニア吸着に関しては,すでにさ まざまな報告がなされている5)-11)。Tamonらは, 酸性官能基を 導入した活性炭について, ヘリウム中の分圧が $6 \mathrm{kPa}$ までのア ンモニア吸着等温線を測定し, 酸性官能基導入がアンモニア
吸着特性を向上させること, $423 \mathrm{~K} て ゙$ 再生処理をしても脱離し ない不可逆成分があり, 1 回目の吸着に比べ2回目以降の吸着 量が大きく低下することを報告している5)。また, DomingoGarciaらは, 脱離しにくい不可逆成分が表面官能基だけでなく ミクロ孔にも起因して起こるため, 表面官能基量のTPD測定に おいて誤った結果を与える場合があることを報告している9”。 アンモニア吸着に関しては, 塩基性の分子に対しての酸性官 能基という直接的な関係が注目されがちで, 本来活性炭の吸 着特性を決定するもう一方の重要要素である細孔という物理 的構造が無視される傾向があるが, Domingo-Garciaらの報告 はミクロ孔がアンモニア吸着の重要な因子であることを示唆 している。酸性官能基を導入した活性炭へのアンモニア吸着 についてのこれまでの報告は, 触媒表面の酸性基解析法とし て, あるいはアンモニア吸収材として, 実用的な見地からのも のがほとんどである。そのため, 実用に近い条件として希薄 濃度のアンモニア混合ガスを吸着させる手法が採用され，ま た報告例ごとに濃度条件などもさまざまである。しかしなが ら, 吸着材のどのような物理的あるいは化学的構造を制御す

\footnotetext{
* Corresponding Author, E-mail: h.hatori@ aist.go.jp

* 産業技術総合研究所：テ305-8569 茨城県つくば市小野川16-1

* National Institute of Advanced Industrial Science and Technology : 16-1 Onogawa, Tsukuba 305-8569, Japan

** 福岡県工業技術センター・インテリア研究所：テ831-0031 福岡県大川市上巻405-3

** Interior Design Research Institute, Fukuoka Industrial Technology Center : 405-3 Agemaki, Okawa, Fukuoka 831-0031, Japan

*** (株ピラミッド： テ 830-0063 福岡県久留米市荒木町荒木1178

*** Pyramid corporation : 1178 Araki, Araki-machi, Kurume, Fukuoka 830-0063, Japan

*****九州大学大学院農学研究院：干812-8581 福岡市東区箱崎 6-10-1

**** Graduate School of Agriculture, Kyushu University : 6-10-1 Hakozaki, Higashi-ku, Fukuoka 812-8581, Japan
} 
ることで吸着特性が向上するか，またそれがどのような分圧 条件に执いて有効かといった基本的な情報を得るためには， 平衡条件に扔いてアンモニアの吸着測定を行い, 官能基への 吸着挙動と細孔への吸着挙動の両方を明確にする必要があ る。そこで, 本研究では, アンモニア吸着で想定される表面酸 性官能基への化学吸着成分と細孔への物理吸着成分を定量的 に評価し, 活性炭へのアンモニア吸着特性を決定づける因子 を明らかにすることを目的に検討を行った。

一方, 木炭は八ウスシックガスの除去などを目的に一般家 庭の室内に置かれるなど, 身近な環境浄化材料として近年注 目されている。木炭は天然素材をイメージさせる商品である ことから, その特性次第で, 使う人に安心感を与える優れた機 能性材料となるものと期待される。さらに, 地球温暖化問題 を背景としたバイオマスの利用拡大，あるいは建設リサイク ル法の施行による建築廃材処理といった社会情勢から, 木質 系素材の有効利用は社会的要請でもあり,木質系原料からの 機能性炭素材料に関しては近年さまざまな報告がなされて (いる(2)-14)。アンモニアは尿臭の原因物質であるが, この尿臭 の除去は快適な生活環境を得る上で病院や高齢者介護の現場 では特に重要であり,すでに木炭の尿臭除去機能に着目した 製品の販売が実際に行われている(5)。木炭の吸着特性は原料 によって異なることが知られ, 種々の化学物質の吸着が詳細 に検討されている(2).16).17)が, アンモニア吸着に関して言えば, 実用的な観点からの検討がほとんどであり, 炭素表面の酸性 官能基との関係のみに着目して吸着活性が議論されている点 は, 先に述べた活性炭の場合と同様である。しかしながら, 本 研究において, 表面酸性官能基以外の要因が木炭のアンモ二 ア吸着特性に大きな影響を与えていることを示す結果が得ら れたので合わせて報告する。

\section{2. 実 験}

\section{1 試料}

試料として, 市販の粒状活性炭 (AC ; シラサギ, 武田薬品工 業)ならびに竹炭 (BC; Bamboo Charcoal, 福岡県立花町産) を用いた。表面酸性官能基の導入は液相酸化法(8). 19), 寸なわ ち試料 $2 \mathrm{~g}$ を $383 \mathrm{~K} て ゙ 2$ 時間乾燥後, 過硫酸アンモニウム (和光純 薬特級) の $1.00 \mathrm{~mol} / \mathrm{L}$ 水溶液 $100 \mathrm{~mL}$ 中に浸し, 室温で所定の時 間捝拌することによって行った。液相酸化後の試料は蒸留水 で洗浄し, 383Kで一晚減圧乾燥した。液相酸化した試料は, ox-AC-48 (48時間液相酸化処理した活性炭)のように, 原試料 名にox-ならびに処理時間を付加して表した。

\section{2 測定}

77Kでの窒素吸着はBELSORP28SA（日本ベル社製）を用

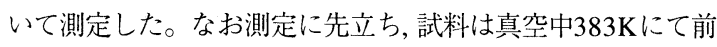
処理を行った。試料の全表面酸性官能基 (AFG; Acidic Functional Groups) 量の測定は, Boehmの方法201によって行った。 吸着測定用のアンモニアガス (昭和電工製) は純度 $99.999 \%$

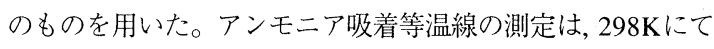
BELSORP18 (日本べル社製)を用いて行った。この際, 試料 を $383 \mathrm{~K}, 10^{-1} \mathrm{~Pa}$ 以下にて真空排気後, 吸着等温線測定を行い 一次吸着等温線を得た後, $298 \mathrm{~K}, 10^{-1} \mathrm{~Pa}$ 以下にて 1 時間排気後 に二次吸着等温線を測定した。一次吸着等温線は試料の全吸 着活性サイトに対する吸着等温線であり，二次吸着等温線は 298Kで吸脱着する弱い吸着ポテンシャルをもつ活性サイト (物理吸着サイト)への吸着等温線である。さらに, 一次等温 線と二次等温線との差から, 298Kでは脱離しない高い吸着ポ テンシャル(あるいは強い結合エネルギー)をもつ活性サイト (化学吸着サイト)への差分吸着等温線を算出した。

\section{3. 結果と考察}

\section{1 酸性官能基導入による細孔構造の変化}

各試料の77Kでの窒素吸着等温線より求めた細孔構造パラ メー夕をTable 1 に示す。ミクロ孔容量 $V_{\text {mirro }}$ ならびに外部比 表面積 $A_{\mathrm{cx} 1}$ は, 無孔性炭素を標準にした $\alpha_{s}$ 解析 ${ }^{211}$.22) により決定 した。さらに細孔をスリット型と仮定して,Wickeの方法 ${ }^{23} に$ よって平均細孔径 $w_{\mathrm{avc}}$ を求めた。 $\mathrm{BC}$ に関しては, 測定におい て吸着平衡到達が極めて遅く, 窒素吸着等温線のヒステリシ スが, 相対圧 0.3 以下でも一致しない現象が見られたことから， ウルトラミクロ孔の発達が示唆された。このような場合, $77 \mathrm{~K}$ における窒素吸着による正確な細孔構造評価は困難であるこ とから, AC との比較のため未処理BCの結果のみを示し, 液相 酸化処理による変化は298Kにおける二酸化炭素吸着等温線 をDubinin-Radushkevich式 ${ }^{24}$.25) にて解析し求めたミクロ孔容 積にて評価した。

Fig.1にACの液相酸化処理時間と全表面酸性官能基量との 関係を示す。ACの酸性官能基量は, 液相酸化処理時間の長さ によって増加し, 24時間以内の処理で急激に増大した後, 6日 間までの長時間処理でさらに増加していく傾向が見られた。 本液相酸化法は, 室温で溶液に浸しておくという極めて簡便

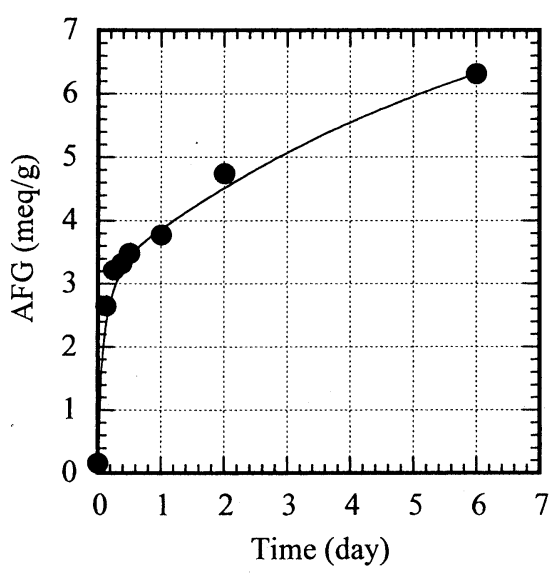

Fig.1 Change in the amount of acidic functional groups on $\mathrm{AC}$ with treatment time in aqueous $\left(\mathrm{NH}_{4}\right)_{2} \mathrm{~S}_{2} \mathrm{O}_{8}$ solution. 
Table 1 Porosity parameters determined from nitrogen adsorption isotherms $(77 \mathrm{~K})$ and the total amount of acidic functional groups (AFG) .

\begin{tabular}{lccccc}
\hline Sample & $\begin{array}{c}A_{\mathrm{BET}} \\
\mathrm{m}^{2} \mathrm{~g}^{-1}\end{array}$ & $\begin{array}{c}V_{\text {micro }}{ }^{*} \\
\mathrm{~cm}^{3} \mathrm{~g}^{-1}\end{array}$ & $\begin{array}{c}A_{\text {ext }} \\
\mathrm{m}^{2} \mathrm{~g}^{-1}\end{array}$ & $\begin{array}{c}w_{\text {ave }} \\
\mathrm{nm}\end{array}$ & $\begin{array}{c}\mathrm{AFG} \\
\mathrm{meq} \mathrm{g}^{-1}\end{array}$ \\
\hline AC & 1484 & 0.564 & 70 & 0.75 & 0.2 \\
ox-AC-3 & 1292 & 0.483 & 82 & 0.75 & 2.7 \\
ox-AC-48 & 1187 & 0.441 & 87 & 0.75 & 4.8 \\
ox-AC-144 & 748 & 0.290 & 67 & 0.76 & 6.3 \\
BC & 227 & $0.089(0.239)$ & 13 & 0.78 & 0 \\
ox-BC-48 & - & $-(0.239)$ & - & - & 0.3 \\
ox-BC-168 & - & $-(0.262)$ & - & - & 0.4 \\
\hline
\end{tabular}

$A_{\text {BET }}$ :BET surface area, $V_{\text {micro }}$ :Micropore volume $(*$ micropore volume determined from $\mathrm{CO}_{2}$ adsorption isotherms at $298 \mathrm{~K}$ using DR equation in parenthesis), $A_{\text {ext }}$.external surface area, $w_{\text {ave }}$ :average micropore width.

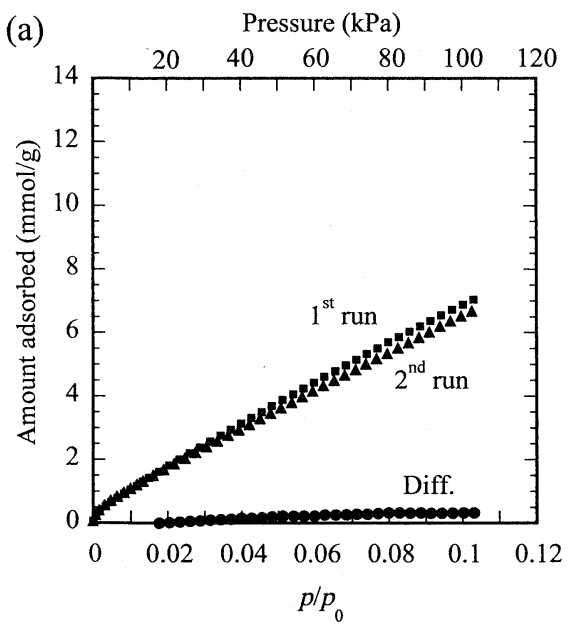

Table 2 The amount chemisorbed and BET parameters on ammonia physisorption at $298 \mathrm{~K}$.

\begin{tabular}{lcccr}
\hline Sample & $\begin{array}{c}V_{0.1} \text {-Chem } \\
\mathrm{mmol} \mathrm{g}^{-1}\end{array}$ & $\begin{array}{c}A_{\mathrm{BET}} \text {-Phys } \\
\mathrm{m}^{2} \mathrm{~g}^{-1}\end{array}$ & $\begin{array}{c}v_{\mathrm{m}} \\
\mathrm{cm}^{3} \mathrm{~g}^{-1}\end{array}$ & $C$ \\
\hline AC & 0.3 & 1877 & 499 & 4 \\
ox-AC-3 & 2.1 & 884 & 235 & 29 \\
ox-AC-48 & 3.8 & 841 & 224 & 39 \\
ox-AC-144 & 5.3 & 722 & 192 & 50 \\
BT & 0.3 & 396 & 105 & 53 \\
ox-BT-48 & 0.5 & 397 & 105 & 76 \\
ox-BT-168 & 0.5 & 410 & 109 & 67 \\
\hline
\end{tabular}

$V_{0.1}$-Chem:amount chemisorbed at $p / p_{0}=0.1$ calculated from the difference between $1^{\text {st }}$ run and $2^{\text {nd }}$ run isotherms,

$A_{\mathrm{BET}}$-Phys:BET surface area determined from $2^{\text {nd }}$ run isotherm, $v_{\mathrm{m}}, C$ :parameters from BET plot of $2^{\text {nd }}$ run isotherm.

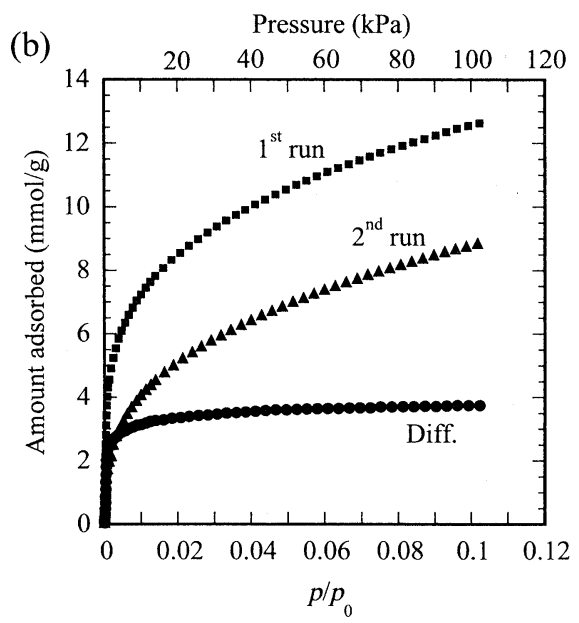

Fig.2 Adsorption isotherm (298K) of ammonia on (a) AC and (b) ox-AC-48; $1^{\text {st }}$ run after vacuum at $383 \mathrm{~K}, \boldsymbol{\Delta} 2^{\text {nd }}$ run after vacuum at $298 \mathrm{~K}$, difference between $1^{\text {st }}$ run and $2^{\text {nd }}$ run.

な方法によって大量の酸性官能基を導入できることから, 低 廉性を特徵の1つとする活性炭の特性改善法として赛用的な 方法と言えよう。Table 1に示すように, ACのBET比表面積 $A_{\mathrm{BET}}$ ならびにミクロ孔容量 $V_{\text {micro }}$ は, 表面官能基導入量が増加す るにつれて減少した。しかしながら，ミクロ孔の平均細孔径 $w_{\text {ave }}$ には大きな変化は見られないことから, 酸性官能基の導入 はミクロ孔の入り口付近で起こり,それが細孔への窒素分子 の侵入を妨げる結果, 細孔容量が低下するものと考えられる。

一方, BCに関しては,7日間の処理によっても酸性官能基量 の増加量はわずかであり，また細孔構造もほとんど変化して いないと考えられる(Table 1)。BCはACに比べて外部表面 積が小さいことから, 官能基導入が可能な部位が少ないこと が一因と推察される。

\section{2 酸性官能基導入による活性炭のアンモニア吸着特性の} 変化

Fig.2に, ACの液相酸化処理前後のアンモニア吸着等温線
（298K）を示す。未処理の活性炭AC (Fig.2a) に関しては,ま ず一次吸着等温線 ( $1^{\mathrm{st}}$ run) と二次吸着等温線 ( $2^{\text {nd }}$ run) の差は ほとんどない。これは1"runで吸着したアンモニアのほとん どが $2^{\text {nd }}$ runの測定前処理である298Kでの排気で脱離するこ とを示している。また，その等温線は，吸着量がほぼ圧力に比 例して増加するHenry的な吸着挙動を示している。Helminen らは,市販の活性炭数種に関して, 100kPaまでのアンモニア吸 着等温線がHenryあるいはLangmuir近似で表されることを報 告しているが，その等温線はACのそれ (Fig.2a) とよく類似し ている(10)。一方, 48時間液相酸化処理した試料ox-AC-48の等 温線 (Fig.2b) は, 未処理ACのそれとは大きく異なり,酸性官 能基導入がアンモニア吸着挙動に大きく影響することを示し ている。まず第 $1 に, 1^{\text {st }}$ runと $2^{\text {nd }}$ runで等温線に大きな違いが 表れ，その差分を算出して描いた等温線 (Diff.) は相対圧0.01 以下でほぼ吸着量が飽和するLangmuir型となった。この差

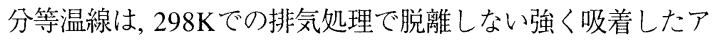


ンモニアの吸着等温線である。Table 2に示したDiff.の相対 压0.1 (100kPa) での吸着量 $V_{0.1}$-Chemは, カルボキシル基やフ エノール性水酸基といった酸性の官能基に対して1対1でアン モニアが化学吸着すると仮定すると,いずれの試料でも全表 面酸性官能基量AFG (Table 1) にほほ対応している。詳細に 見ると $V_{0.1}-$ ChemがAFGを下回る傾向が見られ，これはアルカ リ水溶液を用いるBoehm法ではラクトン型の官能基か加水分 解して酸性官能基としてカウントされるが, アンモニア吸着 ではそれがカウントされないことが原因と推察される。今回 のアンモニア吸着の結果で官能基導入量か増加するにつれて $\mathrm{AFG} と V_{0.1}-\mathrm{Chem}$ のずれが大きくなる傾向が見られるが, 過硫 酸アンモニウムを用いた酸性官能基導入では官能基量が増加 するとラクトン型官能基量の割合が増えることがすでに報告187 されており，上記の仮説を支持する結果となっている。この ように化学吸着量と官能基量との間にほぼ1：1の等量関係が 示されたことから,アンモニアと酸性官能基が気相反応でア

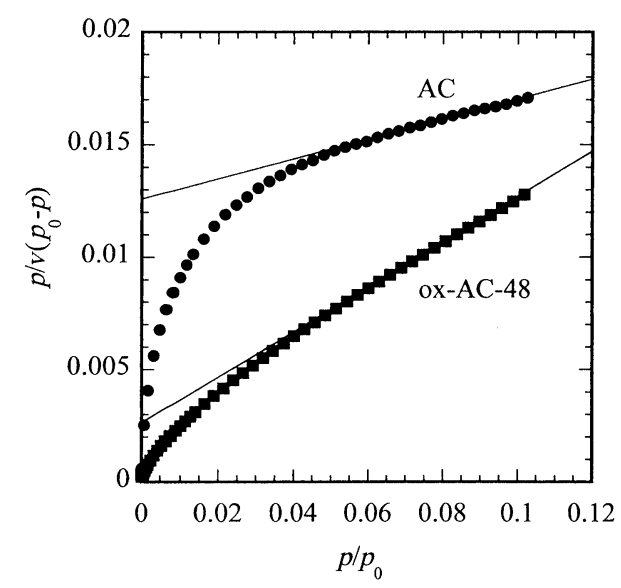

Fig.3 BET plots of ammonia physisorption $\left(2^{\text {nd }}\right.$ run $)$ on $A C$ and ox-AC-48.

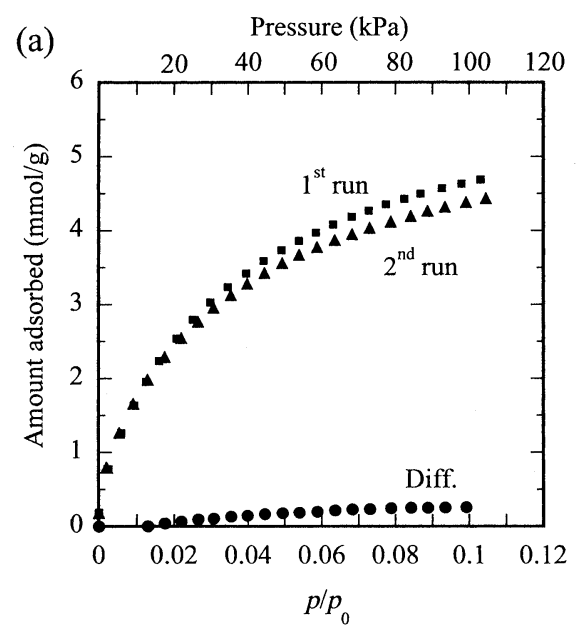

ンモニウム塩を形成していると考えるのが妥当であろう。

二次等温線 ( $2^{\text {nd }}$ run) は, 化学吸着サイトが埋まった表面状態 での, 物理吸着成分の吸着挙動を示しているが, これもox-AC と末処理のACとは大きく異なった。Fig.3に, 可逆的な物理吸 着成分の等温線である2 $2^{\text {nd }}$ runのBETプロットを示す。いずれ のプロットも相対圧 0.05 以上で良好な直線を与え, BET式 (1) に基づき, Table 2に示したようなパラメータが得られた。

$$
v=\frac{v_{\mathrm{m}} C p}{\left(p_{0}-p\right)\left[1+(C-1)\left(p / p_{0}\right)\right]}
$$

ここで $v$ は圧力 $p$ における吸着量, $v_{\mathrm{m}}$ は単分子層吸着量, $C$ は吸 着熱を反映した定数である26)。窒素吸着により求められる BET比表面積とアンモニアによるそれとを比較すると, 化学 吸着が起こった後の物理吸着可能な表面積は明らかに低下す ることがわかるが, その一方で定数Cの変化が示すように, ア ンモニア分子と炭素表面との間の吸着ポテンシャルが酸性官 能基を導入した試料では明らかに向上する。その結果として， Fig.2に見られるように, 0.1以下の相対圧においては, 物理吸 着成分 $\left(2^{\text {nd }}\right.$ run ) についても, 酸性官能基導入によって吸着が 促進された。吸着ポテンシャルの向上の理由としては, 無極 性であった炭素表面に極性部位ができることで, 極性分子で あるアンモニアとの間に双極子相互作用などの作用力が生じ たことによると考えられる。

\section{3 竹炭のアンモニア吸着特性}

竹炭BCに関しては, 酸性官能基がほとんど導入されず, 細 孔構造の変化も小さい (Table 1)ことに対応して, アンモニア 吸着挙動 $($ Fig.4, Fig.5) は液相酸化処理前後でほとんど変化し

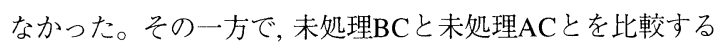
と, 物理吸着成分の等温線 (Fig.2a, Fig.4a) ならびにそのBET 解析の結果 (Table 2) において, その違いは顕著である。特筆 すべきは, 窒素吸着により求められるミク口細孔容量の大き

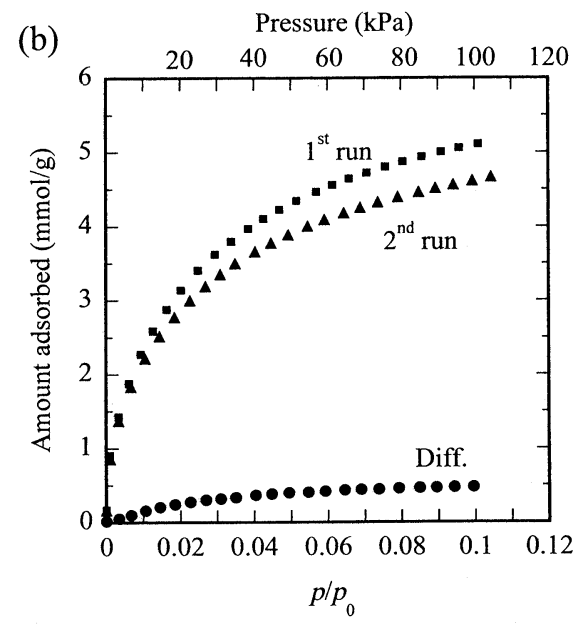

Fig.4 Adsorption isotherm (298K) of ammonia on (a) BC and (b) ox-BC-48; $1^{\text {st }}$ run after vacuum at $383 \mathrm{~K}, \boldsymbol{\Delta} 2^{\text {nd }}$ run after vacuum at $298 \mathrm{~K}$, difference between $1^{\text {st }}$ run and $2^{\text {nd }}$ run. 


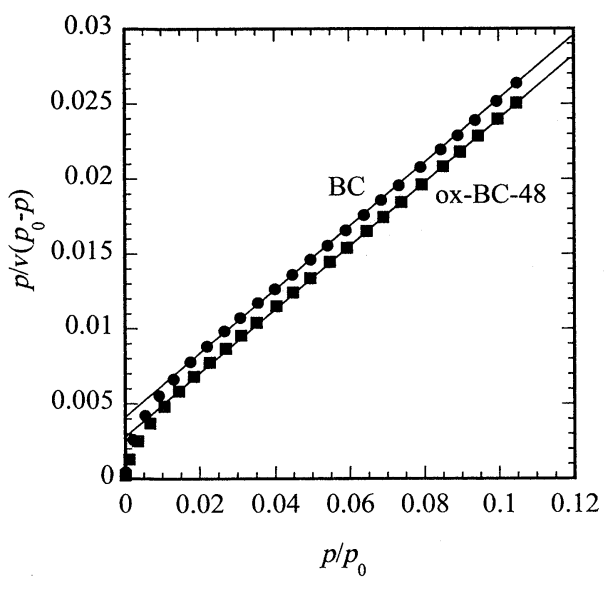

Fig.5 BET plots of ammonia physisorption ( $2^{\text {nd }}$ run $)$ on BC and ox-BC-48.

な違いに比して, 吸着等温線の比較 (Fig.2a, Fig.4a) から明ら かなように, BCのアンモニア吸着量は相対圧0.1でACとほぼ 同等, 相対圧 0.05 以下ではBCの吸着量のほうが優っている。 $\mathrm{AC}$ と BCの酸性官能基量はほぼ同程度であることから, その物 理吸着挙動の違いは, 酸性官能基以外の要因によることは明 らかである。BCにおいて,アンモニア吸着によって求められ るBET比表面積は, 窒素吸着により求められるそれよりも明 らかに大きく, BCにウルトラミクロ孔が存在することを示唆 していることから, 窒素吸着で評価できないウルトラミクロ 孔の高い物理吸着ポテンシャルが, 低相対圧領域のアンモニ アの物理吸着を支配していると推察される。この推察を支持 する結果として, ポリイミドから得られる分子篩炭素27), 28)(細 孔径0.4〜0.5nm) に対して同様の解析を行ったところ, 竹炭 $\mathrm{BC}$ と同等のC值を与えることが明らかになっている。このよ うなウルトラミクロ孔への極性分子の吸着挙動に関しては, 別途報告の予定である。

悪臭の除去など実用面で考えた場合, 低濃度でのアンモ二 アの吸着除去能力が問われるが, 竹炭BCのアンモニアに対す る物理吸着能力は今回用いた活性炭よりも低相対圧で高いと いう特徴があり,アンモニア吸着材として適していると言え よう。

\section{4. 結 論}

活性炭ACのアンモニア吸着特性は, 表面酸性官能基の導入 によって大きく変化した。悪臭の除去など実用面で考えた場 合, 低濃度アンモニアの吸収除去能力が問われるが, 活性炭へ の酸性官能基導入は, 化学吸着量の増加ならびに物理吸着能 力の改善という2つの効果があることが明らかとなった。一 方, 竹炭に関しては, 酸性官能基導入が困難であったが, アン モニアの物理吸着能力に関しては, 今回用いた活性炭よりも 低相対圧で吸着能力が高いことが明らかになった。

\section{謝 辞}

本研究は, 平成14年度経済産業省受託研究費中小企業支援 型研究開発の支援により行われた。

\section{文 献}

1）藤元 薰, 鈴木基之, 真田雄三編, 新版活性炭一基礎と応 用一, 講談社 (1992).

2) C. Shin, K. Kim and B. Choi, J. Chem. Eng., Jpn 34 (2001) 401-406.

3) C. H. Turner, J. Pikunic and K. E. Gubbins, Molecular Physics 99 (2001) 1991-2001.

4) Z. Kowalczyk, S. Jodzis, W. Rarog, J. Zielinski, J. Pielaszek and A. Presz, Applied Catalysis A184 (1999) 95-102.

5) H. Tamon and M. Okazaki, Carbon 34 (1996) 741-761.

6) C. L. Mangun, K. R. Benak, M. A. Daley and J. Economy, Chem. Mater. 11 (1999) 3476-3483.

7) C. L. Mangun, R. D. Braatz, J. Economy and A. J. Hall, Ind. Eng. Chem. Res. 38 (1999) 3499-3504.

8) M. Domingo-Garcia, A. J. Groszek, F. J. Lopez-Garzon and M. Perez-Mendoza, Applied Catalysis A233 (2002) 141-150.

9) M. Domingo-Garcia, A. J. Groszek and M. Perez-Mendoza, J. Colloid Interface Sci. 248 (2002) 116-122.

10) J. Helminen, J. Helenius and E. Paatero, J. Chem. Eng. Data 46 (2001) 391-399.

11) F. Xie, J. Phillips, I. F. Silva, M. C. Palma and J. A. Menendez, Carbon 38 (2000) 691-700.

12) I. Abe, S. Iwasaki, Y. Iwata, H. Kominami and Y. Kera, TANSO 1998 [No.185] 277-284 [in Japanese].

13) K. Shibano, S. Yoshizawa, S. Goto and Y. Ogawa, TANSO 2002 [No.204] 166-170 [in Japanese].

14) R. Asakura, M. Morita, K. Maruyama, H. Hatori and Y. Yamada, J. Mat. Sci., submitted.

15）泉田博志, 公開特許 2000-70658.

16) M. Hitomi, Y. Kera, H. Tatsumoto, N. Ikuta, I. Kawafune and I. Abe, TANSO 1993 [No.156] 22-28 [in Japanese].

17) M. Hitomi, Y. Kera, H. Tatsumoto, I Abe, I. Kawafune and N. Ikuta, TANSO 1993 [No.160] 247-254 [in Japanese].

18) C. Moreno-Castilla, F. Carrasco-Marin and A. Mueden, Carbon 35 (1997) 1619-1626.

19) K. Kushiro, H. Oda and C. Yokokawa, TANSO 1991 [No.148] 151-155 [in Japanese].

20) H. P. Boehm, Angew. Chem. 78 (1966) 627-652.

21) D. Atkinson, A. I. McLeod and K. S. W. Sing, J. Chem. Phys. 81 (1984) 791-794.

22) K. Kaneko, C. Ishii and T. Rybolt, Characterization of Porous Solids III (J. Rouquerol, F. Rodrigues-Reinoso, K. S. W. Sing and K. K. Unger, eds.) (1994) pp.583-592 Elsevier, Amsterdam.

23) B. G. Linsen and A. van den Heuvel "Pore structure", E. A. Flood ed. "The Solid-Gas Interface" Chapter 35, pp.1025-1053.

24) M. M. Dubinin, Chem. Rev. 60 (1960) 235-241.

25）結城仲治, 北川 浩,「分子ふるい炭素の製造とその性能 に関する研究」, 公害資源研究所報告第23号 (1982).

26）近藤精一, 石川達雄, 安部郁夫, 吸着の科学 (1991) pp.3197, 丸善.

27) H. Hatori, Y. Yamada, M. Shiraishi, H. Nakata and S. Yoshitomi, Carbon 30 (1992) 305-306.

28) H. Hatori, Y. Yamada, M. Shiraishi, H. Nakata, S. Yoshitomi, M. Yoshihara and T. Kimura, TANSO 1995 [No.167] 94100 [in Japanese]. 